\title{
$\mathbb{X}$ 線光電子分光法用起䈌型区線源の球面收差と ビーム隔状シミュレーション
}

\author{
岩井秀夫 · 大岩 烈 · Paul E. LARSON* . 工藤正博** \\ アルバック・ファイ（株）（丞253神奈川県茅ヶ崎市萩園 2500 \\ *Physical Electronics inc. 6509 Flying Cloud Drive, Eden Prairie, Minnesota 55344 \\ **成蹊大学工学部 $\quad$ =180 東京都武蔵野市吉祥寺北町 3-3-1
}

（1995年 4 月 3 日受付，1995年 5 月 10 日掲載決定）

\section{Spherical Aberration and Beam Shape Simulation of Scanning X-ray Source for X-ray Photoelectron Spectroscopy}

\author{
Hideo Iwai, Retsu Oiwa, Paul E. Larson* and Masahiro Kudo** \\ ULVAC-PHI, INC. \\ 2500 Hagisono, Chigasaki-shi, Kanagawa 253 \\ *PHYSICAL ELECTRONICS INC. \\ 6509 Flying Cloud Drive, Eden Prairie, Minnesota 55344, USA \\ **Department of Applied Physics, Faculty of Engineering, Seikei University \\ 3-3-1 Kitamachi, Kichijyoji, Musashino-shi, Tokyo 180
}

(Received April 3, 1995 : Accepted May 10, 1995)

\begin{abstract}
Simulation of the spherical aberration and beam shape of scanning X-ray source for X-ray Photoelectron Spectroscopy(XPS) has been investigated for optimization of optics and estimation of beam size. The scanning $X$-ray source used for this study is equipped with an elliptical mirror to diffract and focus aluminum $\mathrm{K} \alpha \mathrm{X}$-ray. The anode from which $\mathrm{X}$-ray is excited, is located on the elliptical mirror focal point, and $X$-ray source point is projected near the other side of the focal point(sample). At the optical center, it is simulated that there exists no spherical aberration. On the other hand, lineally increasing spherical aberration is observed according to the distance from the optical center both in a horizontal and vertical direction. It is concluded that $10 \mu \mathrm{m}$ beam is applicable if tolerance of alignment is within $\pm 40 \mu \mathrm{m}$ both in horizontal and vertical direction. Using a tungsten mesh(grid) sample, the X-ray beam shape is experimentally measured as $8.7 \times 10.5 \mu \mathrm{m}$ beam. These values are compared with those obtained by simulation and some of the factors influencing results are discussed in detail.
\end{abstract}

\section{1. 緒言}

X 線光電子分光法 (XPS) は，1970年初期から使われ 始めた代表的な表面分析法である1)。XPS はオージェ電 子分光法 (AES : Auger Electron Spectroscopy) や 2 次 イオン質量分析法 (SIMS : Secondary Ion Mass Spectrometry) と比較すると, 原子の結合状態の情報を抽出 できるため, 化学状態分析が可能なことが大きな特徵で ある。しかし，プローブがX線であるため荷電粒子ビー
ムのような微小化が困難で, 微小領域分析は立ち遅れて いるといえる。今日では, 電子分光器の入射レンズで視

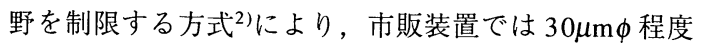
の分析ができるようになった3)。また，光電子をエネル ギー分光した後に画像投影する方式を用いた場合4,5), 感度の高い元素では $2 \mu \mathrm{m}$ 程度の空間分解能で元素マッ プの取得ができる。しかし，これらの方法では，微小な 空間分解能で高いエネルギー分解能を維持して光電子ス ペクトルの取得が難しく，スペクトル分光法という観点 
からは不十分な方式といえる。また，シンクロトロン放 射光と回折集光ミラーを利用してX線をマイクロフォー カスする方法 ${ }^{6-8)}$ があるが, 施設が大がかりで一般的で ない。

一方，細く絞った電子ビームをアノードに照射するこ とで軟 X 線の発生領域を小さくし, 回折集光ミラーでX 線を単色集光させる方式は9), AES やSIMSのようにX 線ビームを走査できるため, 元素マップの取得や多点分 析が容易になる可能性が高い。また, 試料上へのX線照 射を均一に行える可能性があることから, 周辺効果を除 去するためのゲーティングを施すと，有機物やセラミッ クスなどの絶縁物測定の際に発生する部分帯電 ${ }^{10)}$ を少な くできることが期待できる。このように, 走査型 $\mathrm{X}$ 線源 は非常に有望なプローブであるが, 実現可能な最小ビー 么径, 走查領域の中心と周辺でのビーム形状変化の知見 はほとんど得られていない。そこでわれわれは，走査型 $\mathrm{X}$ 線源の球面収差とビーム形状を調べる目的で, コン ピュータを使ったシミュレーションを行い，実際に作製 した走査型 X線源を用いてビーム径測定の実験を行い， 比較検討を行った。

\section{2. アルゴリズム}

\section{1 計算}

本研究では, 3 次元空間における回転棈円体の焦点 近傍（アノード）を出発点とし，棈円面で反射された後 に，もう一方の焦点近傍 (試料)に集光したときの球面 収差とビーム形状を計算した。計算するに当たり, 理想 的な回転棈円回折ミラーと仮定し, 励起 X線の面方向の 強度分布は電子線の強度分布と等しくガウス分布とし, $\mathrm{X}$ 線の波長分布は無視した。

Fig. 1 は, 走查型 $\mathrm{X}$ 線源の断面の模式図で, 3次元座 標の中心を回転棈円体の中心 $\mathrm{O}$ とし, 楕円断面の長軸 を $Y$ 方向, 単軸を $X$ 方向にして, ミラー中心の座標を $(-a, 0,0)$ に配置した。ミラーは, $Y Z$ 平面に平行に配 置した。また, アノードと試料の傾斜角 $\alpha, \beta$ を, X 線の ブラッグ角と, 各機器の位置の制約上, それぞれ11.46度 にした。X 線は $Y Z$ 平面あるいはそれの傾いた面におい て出射，入射する。

$\mathrm{X}$ 線の反射に用いる回転楕円体は, つぎのような方程 式で表わすことができる。

$$
\frac{X^{2}}{a^{2}}+\frac{Y^{2}}{b^{2}}+\frac{Z^{2}}{c^{2}}=1
$$

$X, Y, Z$ は棈円面の変数である。今回計算に用いた回転 棈円回折ミラーは, 大きさが $40 \times 40(\mathrm{~mm}), a=c$, 長軸 $b$ が $196 \mathrm{~mm}$ であるため, 次式より短軸 $a$ を求めた。

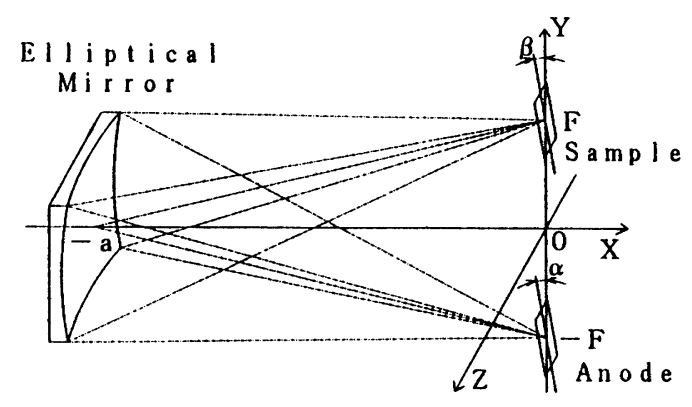

Fig. 1 Diagram of Coordinates for a simulation model of a scanning X-ray source.

$$
a=\frac{b \lambda}{2 d}
$$

ここで $\lambda$ は $\mathrm{AlK} \alpha_{1}$ 特性 X 線の波長 $0.833934 \mathrm{~nm}$ であり, $d$ は石英 (100) 面の格子定数 $0.425444 \mathrm{~nm}$ である。この とき楕円の焦点距離は, 中心からの長さとして次式で表 わすことができる。

$$
F=\left(b^{2}-a^{2}\right)^{1 / 2}
$$

球面収差の計算は, アノードからの X線の射出の基準を $(0,-F, 0)$ にとり, この近傍で位置を変えながらもう一 方の棈円の焦点 $(0, F, 0)$ 近傍の試料上に投影される $\mathrm{X}$ 線を計算して求めた。ビーム形状 (強度プロファイル11) の計算に関しては，X線のビーム径を半值幅で設定し ${ }^{12) 、}$ その 2 倍の大きさのアノード領域を $151 \times 151$ の点に分 割し，それぞれの点から回折ミラーで反射された後に試 料面と交わる座標 (入射点) を求め, 各出発点の $\mathrm{X}$ 線強 度をその座標に積算する方法で強度計算を行った。

\section{2 アルゴリズム}

Fig. 2 は本計算のアルゴリズムを表わしたものであ る。はじめにビーム位置などの入力パラメータを設定し 計算を開始すると, X線発生点から回折集光ミラー各点 への入射ベクトルを計算する。つぎにミラー各点の垂直 ベクトルを計算する。そして, この二つのベクトルから 反射ベクトルを計算し, 試料面の面の方程式と反射べク トルの交点を計算する。試料面はあらかじめ計算してお いた射出 X 線の大きさに応じて配列として分割してお く。交点の座標の配列にガウス分布で計算した 1 次 $X$ 線 の強度を積算する。この計算を繰返し行い, 計算が終了 した時点で, 後の検討のためにビーム強度を XY座標の 並べ方で ASCII 形式で保存し, 市販の表計算ソフト ウェアなどで読み出しができるようにした。計算に用い たコンピュータは IBM/PC 互換機で, プログラムは 32 ビット対応のC 言語コンパイラとDOSエクステンダー を用いて書いた(ソースコードで約 36kbytes)。 


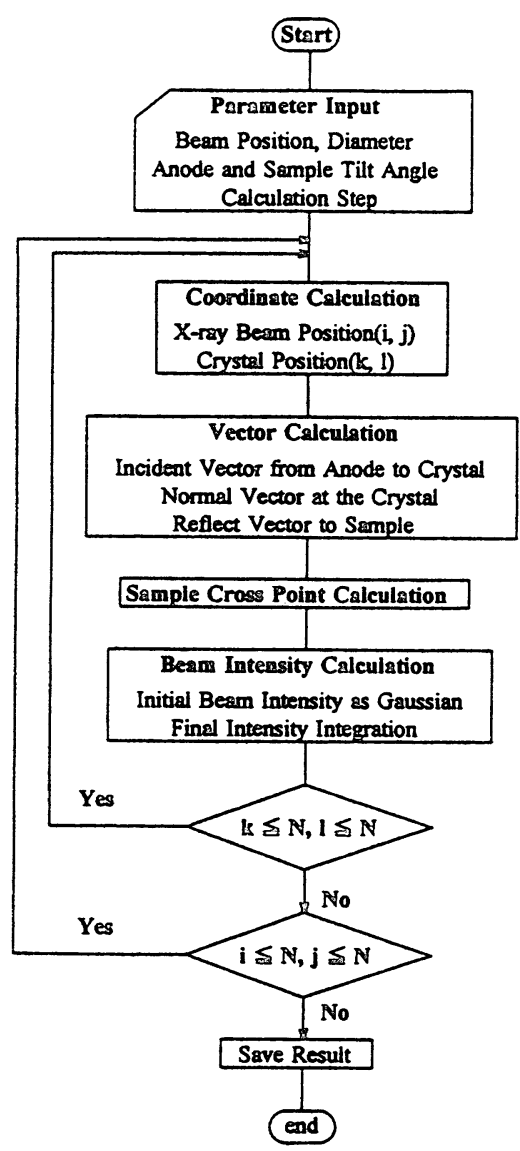

Fig. 2 Simulation algorithm for calculation of X-ray beam shape diffracted from the elliptical mirror.

\section{3. 実験装置および方法}

本研究で作製した走査型 $\mathrm{X}$ 線源とビーム径測定装置の 模式図をFig. 3 に示した。X線モノクロメータは, ロー
ランド直径が約 $200 \mathrm{~mm}$ の石英製回転棈円回折ミラーに $40 \times 40 \times 0.1(\mathrm{~mm})$ の $(100)$ 面石英板を貼り付けたものを 用いた。楕円は, AlK $\alpha_{1}$ 特性 X 線の波長 $(0.833934 \mathrm{~nm})$ と石英格子定数 $(0.425444 \mathrm{~nm})$ とできまるブラッグ角 $\left(78.54^{\circ}\right)$ に一致するよう, 単軸が $192.1 \mathrm{~mm}$, 長軸が $196 \mathrm{~mm}$ の曲面で作製した。X 線励起用電子銃には $\mathrm{LaB}_{6}$ カソー ドを用い, 静電型コンデンサーレンズと対物レンズを用 いて 2 100 $(\mu \mathrm{m} \phi)$ のビーム径が得られるようにした。電 子ビームの偏向は, アルミニウムアノード上で $1 \times 1(\mathrm{~mm})$ の大きさまで走査することができるよう設計した。電子 銃の調整とビーム径の測定は, アノード上にナイフエッ ヂ部を設け, 2 次電子像で行った。X線の検出は, 集光 位置 (試料)に $0.5 \times 0.5(\mathrm{~mm})$ の周期をもつ太さ $0.1 \mathrm{~mm}$ の タングステン $(\mathrm{W})$ グリッドを置き, グリッドの間を通り 抜けた X 線をチャンネルトロンで 2 次電子に変換増幅 し, パルスカウント方式で行った。また, アノードから の 2 次電子のバックグラウンドを除去するため, W グ リッドとチャンネルトロンの入りロに直流で $-2100 \mathrm{~V}$ 印 加した。光軸の微調整を行うため, 電子銃, アノード, W グリッドは真空チャンバー外部から $X Y Z$ 方向に動か

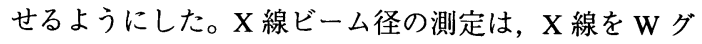
リッド上で線走査するナイフエッヂ法で行った。排気装 置は, イオンポンプとチタンゲッターポンプを組合せた 超高真空排気系を使い, 到達圧力は $7 \times 10^{-8} \mathrm{~Pa}$ である。 また, 2 次電子とイオンのバックグラウンド除去のた め, ポンプとチャンバーの間に直流 $+90 \mathrm{~V}$ のバイアスを 印加したグリッドを設けた。

光軸調整は, 直径 $2 \mu \mathrm{m} \phi$ の電子線を走査しながら行

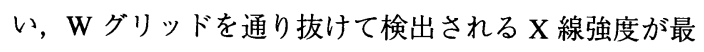
大で, かつグリッドが最も鮮明に観察されるよう, 電子 銃の軸合わせを最適化した。つぎに電子銃の焦点を調整 しながらアノードの高さを変化させ，W グリッド像が

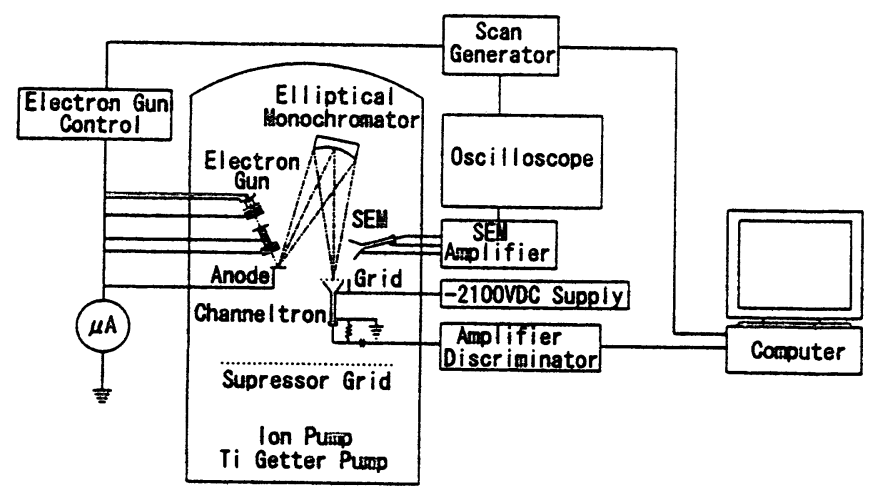

Fig. 3 Experimental apparatus for measurement of the scanning $\mathrm{X}$-ray intensity. 


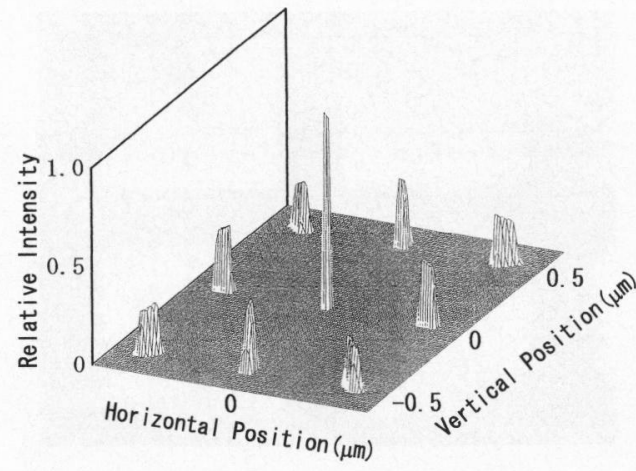

Fig. 4 Diffracted X-ray beam intensity profile from the cross points of $0.5 \times 0.5(\mathrm{~mm})$ mesh on the scanning area.

最も鮮明に観察されるよう，アノード高さを最適化し た。そして，ビーム径を測定しながら W グリッドを上 下に動かして，ビーム径が最小になる位置を探した。な お，像の倍率はグリッド間の距離で較正し，ビーム径は ラインスキャンで得られた強度曲線の 16 84\%の位置 での幅で評価した。

\section{4. 結果と考察}

\section{1 シミュレーション結果と考察}

Fig. 4 は， $1 \times 1(\mathrm{~mm})$ の走査領域を $0.5 \mathrm{~mm}$ 間隔で分割 し，それぞれの交点から射出したX線が試料上に投影さ れる $\mathrm{X}$ 線の形状 (強度プロファイル ${ }^{11)}$ ) を計算したもの である。射出X線は十分細いものとして点で計算した。 中心では点状のビームが得られるが，周辺部ではミラー の形状を反映した歪んだビームになることがわかる。こ れは回転棈円ミラーの球面収差を反映したものである。

Fig. 5 (a) (b) は，射出 X 線の位置 (十方向の変位) に対 する球面収差を計算したものであり，(a) は横方向 $(Y)$,

(b)は縦方向 $(Z)$ の球面収差をプロットした。中心では収 差0となり, 中心からずれるに従い, 直線上で収差が大 きくなることがわかる。一方向の变位も同様の検討を行 い,まったく同じ結果が得られた。得られた結果から球 面収差は次式のように表わせる。

$$
\begin{aligned}
& C_{z}=0.084 Z \\
& C_{y}=0.084 Z+0.16 Y
\end{aligned}
$$

ここで, $C_{z}, C_{y}$ は横方向 $(Z)$ と縦方向 $(Y)$ の球面収差, $Z, Y$ は $X$ 線が射出するアノード面上の座標で, 単位は $\mu \mathrm{m}$ である。したがって，(4)(5)式より光軸から外れ た任意の位置で, ビームの球面収差の大きさを求めるこ とができる。(4)式より, 横方向の球面収差は $Y$ によ (a)

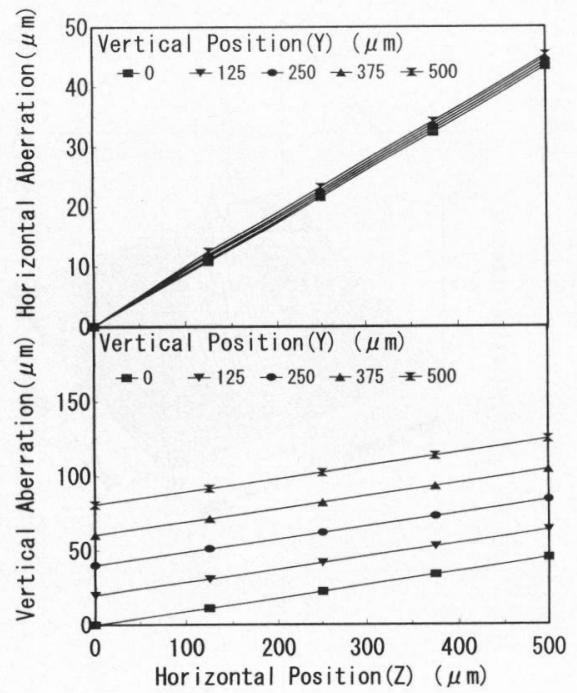

Fig. 5 Spherical aberration size both in the horizontal (a) and vertical (b) directions on the primary $\mathrm{X}$-ray beam as a function of the horizontal and vertical position.

ないため, $Z$ が $120 \mu \mathrm{m}$ 以内であれば $10 \mu \mathrm{m}$ 以下の収差 となる。縦方向の球面収差は， $Z, Y$ 両方向の位置と関 係している。(5) 式の $C_{y}$ に $10 \mu \mathrm{m}$ を代入し， $Z=Y$ とお いて $Z$ を求めると $40 \mu \mathrm{m}$ となり， $Z, Y$ が中心から $40 \mu \mathrm{m}$ 以内に入っていれば，ビーム径は $10 \mu \mathrm{m}$ 以下になること がわかった。ただし，この場合の $C_{z}$ の大きさは $3.4 \mu \mathrm{m}$ となり，縦に細長いビーム形状となる。

$10 \mathrm{kV}$ の加速電圧で十分細い電子線で $\mathrm{Al}$ を励起したと きの X 線発生領域の広がりは, Soezima モデル13)によ り計算すると約 $2 \mu \mathrm{m} \phi$ である。実験装置の電子銃のビー 厶径が $2 \mu \mathrm{m} \phi$ であるため, X 線の広がりを考虑して $4 \mu \mathrm{m} \phi$ の半值幅の $\mathrm{X}$ 線が, アノード中心 $\mathrm{O}$ および $(0.5,0.25) \mathrm{mm}$ の座標 S から射出したときの, 試料上での X 線の強度 プロファイルを計算したものを Fig. 6 (a) (b) に示す。 シミュレーション結果から，Oからのものについては半 值幅 $4 \times 4(\mu \mathrm{m}), \mathrm{S}$ からのものについては $41 \times 73(\mu \mathrm{m})$ の $\mathrm{X}$ 線ビームが得られた。この結果から，Oでは球面収差 の影響は受けず，アノード上でのX線ビーム径と等しい が，中心から外れたSでは，(4)(5)式から求まる球面 収差の大きさと一致することがわかった。

\section{2 実験結果と考察}

Fig. 7 が $10 \mathrm{kV}, 2 \mu \mathrm{m} \phi$ の電子線励起でX線を発生さ せ, $1 \times 1(\mathrm{~mm})$ の範囲で走査し, $0.5 \times 0.5(\mathrm{~mm}) \mathrm{W}$ グリッ ドをチャンネルトロンで測定した像を示したものであ る。写真の中心付近でビームが絞れていることがわか る。この付近のグリッドをラインスキャンしてビーム形 
(a)

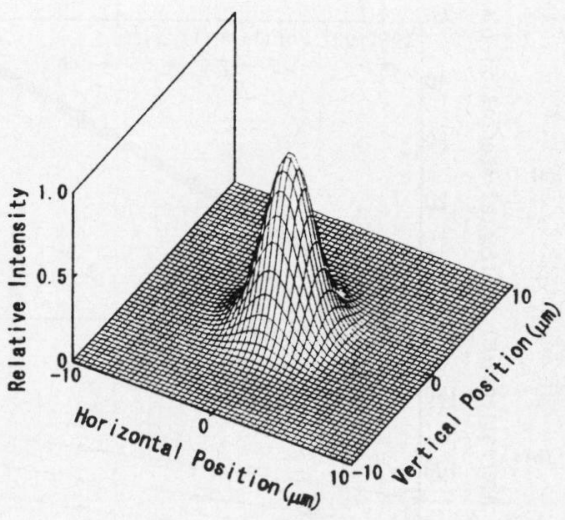

(b)

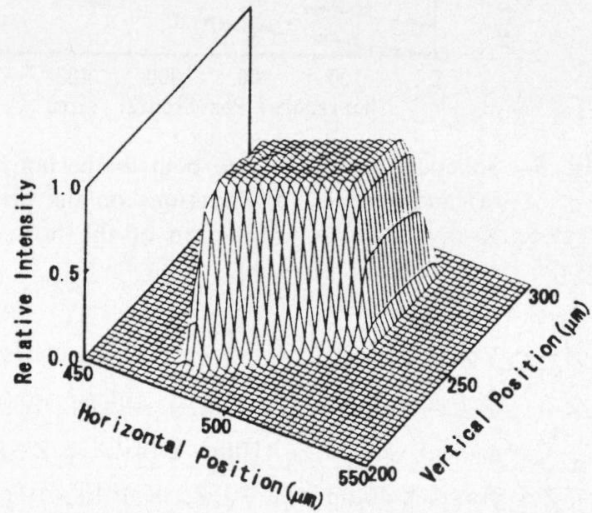

Fig. 6 Simulation results on the intensity profiles of diffracted X-ray beam from optical center $(0,0)$ (a) and off axis position $(0.5,0.25)$ (b) in the scanning area. The diameter of primary $\mathrm{X}$-ray beam is about $10 \mu \mathrm{m} \phi$.

状を測定した結果を，Fig. 8 に示す。16〜84\%で評価 したビーム形状は $8.7 \times 10.5(\mu \mathrm{m})$ であった。励起 X 線の 広がりは，4.1で述べたように約 $2 \mu \mathrm{m}$ であると予測され るため,このことを考慮すると，実測值とシミュレー ション結果の差の理由として, 実測値に関しては

[1] 光軸の調整が不完全である。

という可能性が上げられる。また, シミュレーションに 関しては

[2] 回転棈円回折ミラーが理想的であると仮定したが, 実際は結晶の欠陥や凹凸があるのを考虑に入れな かった。

[3] X線の面方向強度分布をガウス分布と仮定した。

[4] シミュレーションではX線の波長分布を考慮に入 れないで計算した。

などの理由が考えられる。上記四つの中でも [2]が大き く関係していると考え，ミラーを銅板で覆い，ミラーの 大きさを半分にしてビーム形状の測定を行ったところ，

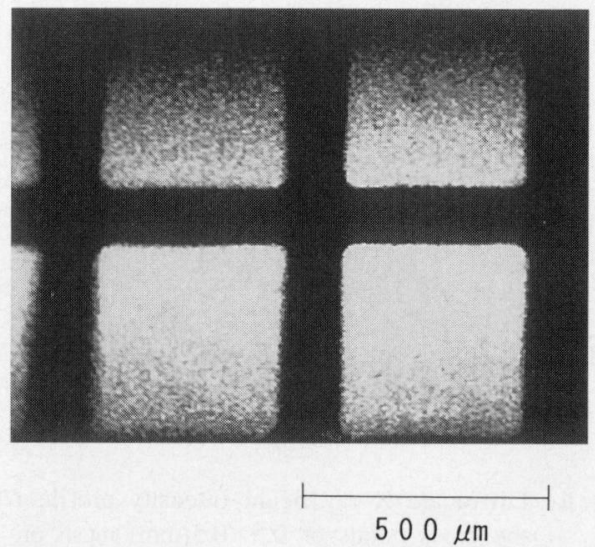

Fig. 7 Scanning $X$-ray image of a $\mathrm{W}$ grid $(0.5 \times 0.5 \mathrm{~mm}$ mesh) measured by the channeltron type electron multiplier.

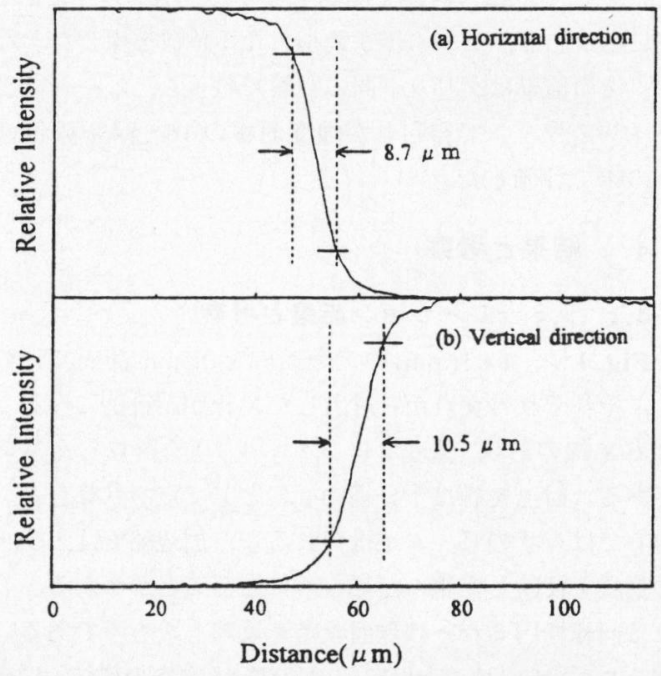

Fig. 8 Diffracted X-ray beam size measured in the horizontal (a) and vertical (b) derections.

$7.3 \times 9.0(\mu \mathrm{m})$ が得られた。この結果を考虑すると, 上記 四つの中では [2] 以外の理由も無視できないことがわ かった。

\section{5. 結 言}

本研究では, 走査型 X 線源に用いる回転棈円回折ミ ラーの球面収差とビーム形状を調べる目的で, コンピュー タシミュレーションを行い, ビーム形状測定実験との比 較検討を行った。その結果は以下のとおりである。

[1] 光軸中心部では球面収差は 0 となる。

[2] 球面収差は, 光軸を外れた位置では，(4)，(5)式 の関係が得られた。

[3] 実験装置の光軸調整を行う場合, 光軸中心からの 
距離が横方向 $(Z)$ 縦方向 $(Y)$ で $40 \mu \mathrm{m}$ 以内に入っ ていれば， $Z, Y$ 方向のビーム径は共に $10 \mu \mathrm{m}$ 以下 になることがわかった。

[4]ビームを光軸中心に置けば，球面収差の影響は受 けないが, 周辺では (4), (5) 式で求まる球面収 差の大きさと一致することがわかった。

[5] 実測で最小 $8.7 \times 10.5 \mu \mathrm{m}$ のビームを得ることがで きたが，この結果は，シミュレーション結果で予 測する数值と比較すると大きく異なってはいない ことがわかったが，完全には一致しなかった。

今後は，シミュレーション精度を上げるために，X 線 の波長分布を考慮に入れた計算が必要と考える。

\section{文献}

1) D. Briggs and M. Seah : "Practical Surface Analysis" (John Wiley 1986).

2) B. P. Tonner, G. R. Harp, S. F. Koranda and J. Zhang : Rev. Sci. Instrum. 63 (1), 564 (1992).

3) I. W. Drummond, F. J. Street, L. P. Ogden and
D. J. Surman : Scanning 13, 149 (1991).

4) M. P. Seah and G. C. Smith : Surf. Interface Anal. 11, 69 (1988).

5) D. Briggs and M. Seah : "Practical Surface Analysis 2nd Edition" (John Wiley 1990).

6) K. Ninomiya, M. Hasegawa and S. Aoki : Jpn. J. Appl. Phys. 30, 2889 (1991).

7) H. Ade, J Kitz, S. Hulbert, E. Johnson, E. Anderson and D. Kern : J. Vac. Sci. Technol. A9 (3), 1902 (1991).

8) H. W. Ade : Nucl. Instr and Meth. : A319, 311 (1992).

9) P. E. Larson and P. W. Palmberg : "Scanning and High Resolution X-ray Photoelectron Spectroscopy and Imaging" US Patent No. 5, 315, 113 (1994).

10) 富塚 仁, 菖蒲明己：表面科学 15, 456 (1994).

11) Y. Suzuki, F. Uchida and Y. Hirai : Jpn. J. Appl. Phys. 28, L1660 (1989).

12) 南 茂雄編：“科学計測のための波形デー夕処理” (CQ出版社, 1986) p. 184.

13) 日本学術振興会第132委員会編：“電子・イオンビー ムハンドブック”（日刊工業新聞社, 1986) p. 639. 